DOI https://doi.org/10.32405/2218-7650-2021-16(45)-140-156

UDC 373.2.02; 373.2

Farida Samedzade,

Ph.d of the Institute of Education

of the Republic of Azerbaijan;

Lecturer of the Azerbaijan State Pedagogical University.

Baku, Azerbaijan.

ORCID ID: https://orcid.org/0000-0002-6397-0886

feridesemedzade@gmail.com

\title{
INSTILLING RESPECT FOR FAMILY TRADITIONS IN PRESCHOOL CHILDREN (LARGE GROUP)
}

\begin{abstract}
Family traditions play a key role in the spiritual and physical development of children, in the formation of the spiritual basis of a healthy lifestyle. Thanks to educational influences, preschool children understand what is good and what is bad, pay attention to their actions, behaviors and attitudes, communication patterns, speech and conversations. Respect is one of the main indicators of a child's spiritual world. The formation of respect is in itself a long-term process. In this regard, it is necessary to start this work at an early age. Over time, a child develops spiritual qualities. As these qualities are formed, the child will be able to communicate with family, parents, peers, and so on. A caring, loving attitude develops. There are important aspects of it, such as respect and attention. The commitment of every nation to its mother tongue, culture and traditions is a guarantee of its permanent existence. This is one of the main reasons why family traditions have been preserved and passed down for centuries. The family is primarily responsible for preserving these values and traditions and passing them on to future generations. One of the main problems of modern times is the protection of the integrity of the socio-spiritual environment. For this reason, the family plays the role of a transmitter of universal values, traditions, cultural heritage, moral norms and rules, which are becoming increasingly important for the citizen, the individual and society. Experts note that in the XXI century, people's need for a family has decreased, and it is evolving towards liberal forms of coexistence under the influence of civilization. However, many pedagogical studies show that this is not the case. For a person, the values of family, children, home, material well-being, and leisure time have greatly increased. This global problem is in the center of the world's
\end{abstract}


attention, and various discussions and challanges are being made to solve it. Seminars and conferences of ministers of a number of influential organizations, including the Organization of Islamic Cooperation (OIC), on «Marriage, the institution of the family and the protection of these values in the Organization of Islamic Cooperation», «Social policy and the family in the Islamic world: requirements and needs» once again showed how relevant it is for the countries of the world. The presence of numerous events on this topic in our country is a clear example of the material and moral support provided by the state, the necessary care. In holding these events, we once again show all the opportunities and conditions for the continuation of our family traditions with dignity. As you know, in December 2019, the first coronavirus COVID-19 was detected in Wuhan, the central Chinese province of Hubei, and from there spread around the world. With the emergence of this deadly virus, it has led to a radical change in many areas that continue to flow normally. As part of the fight against the virus, a pandemic has been declared in almost all countries. Jobs were closed in many sectors. Quarantine regime was applied. People were not allowed to leave their homes. Faced with this situation at a time when the world was unexpected and unprepared, people, including families, have faced problems they had never encountered before. This way, of course, was to find out how the families found a way out when the previous generations did not operate the kindergarten at this level. This path led them to family traditions. These contradictions led them to «rediscover» family traditions. These obligations, in fact, gave a new «breath» to the forgotten family traditions. Prior to this situation, parents were able to spend less time with their children due to long-term stressful work schedules. Also, at a time when these processes are taking place, the people with whom people come in contact are simply their families. One or both of the working parents had the opportunity to spend more time with the family and children than ever before. It was impossible to continue their family traditions in a healthy way. The continuity required in this case was definitely violated. Due to the new situation, families now have ample opportunities to continue the family traditions. The fact that the coronavirus is a deadly virus, and that people cannot actually see family members, family elders, loved ones, and acquaintances, whether they have the means or not, and save their lives, reminded the whole world of the concept of «family». Eating, talking, watching TV, and reminiscing about those days together revived family traditions. Even after the current 
situation is over, such people will not forget these moments and will continue the family traditions that they have redefined. They will not forget that they came out of this financially and psychologically difficult period with the support of family and family traditions. Many families who remember the value of being a family will always respect these traditions. As noted in the pedagogical and psychological literature, the first five years are extremely important in the formation of a person's personality. The fact that preschool children spend this age in a family environment proves to us once again how important and necessary the responsibilities of the family are. From this point of view, the upbringing of a child should be viewed not only as the upbringing of an individual growing up at home, but also as a person who will become a part of society. Therefore, the family, like other institutions, must make the necessary efforts for the comprehensive development of children.

Keywords: family; tradition; family traditions; preschool child; large group; child rearing; parent and pre-school teacher.

\section{INTRODUCTION / ВСТУП / ВВЕДЕНИЕ}

Formulation of the problem. It is clear from the research of experts that this work should begin at a pre-school age. This age is not only the most important age in human life, but also a complex and relatively difficult period in which the foundations of human personality are laid. It is claimed that the features formed at this age are located in his consciousness and will not be forgotten for a lifetime [5].

Traditions have been tested over the years and have survived to the present day. These are the standards accepted by the society. They have been lived for centuries, passed down from generation to generation. Families, which are the core of society, also have traditions within them. If the family continues any activity on a regular basis, this family activity can become a family tradition over time. Every person born is an active participant in this type of activity [1].

Instilling respect for family traditions in preschool children is an integral part of their upbringing. Traditions are the most powerful means of preserving the continuity and unity of the family and teaching children the importance and value of the family. Therefore, family traditions need to be preserved and revived. Family traditions play an important role in the formation and development of the social and spiritual culture of preschool children. With this in mind, parents, grandparents and the younger generation respect and live the customs and traditions that exist in their families. Our surveys, observations and 
research show that this issue is not easy to solve today. When we got acquainted with preschool children and their families, it became clear that the existing pedagogical recommendations do not always work.

The family should also focus on the proper establishment of parent-child, child-child relations. The personal example of a father and mother, their mutual respect, mutual assistance, care, sensitivity and love are examples for children. After all, children learn from adults, especially parents.

Determining the correct position of parents within the family is no less important. In the eyes of the child, neither parent should be in a stronger or weaker position than the other. Consensus is useful when making decisions.

Everything he/she sees and hears in the family is a model in the child's mind. He/she looks carefully at what he/she sees, and then begins to imitate and repeat what he/she sees. He/she tries to say everything hears. Therefore, parents need to pay close attention to what they say and do, especially when they have a child with them.

Preschoolers reluctantly and unconsciously imitate their parents, imitating their fathers and mothers, grandparents and others. Therefore, parents should pay attention to their daily relationships, culture, and set an example for others to follow. For a preschooler, the parent exists from the beginning and is the person they want to be for the child. In the eyes of children, fathers and mothers are the most beautiful, intelligent, brave, courageous, strong, fearless and positive role models. The main arguments in the arguments of preschool children are such statements as «My grandfather said so», «My mother does it». The actions and judgments of parents are not criticized. However, children shape the behaviors they exemplify by observing, analyzing, and comparing [10].

Analysis of the latest relevant research and publications. A study of the available literature shows that educators consider family traditions necessary for a healthy family environment. Conversations with teachers and scholars on the subject, review of programs and textbooks show that respect for these traditions should be nurtured from preschool age. Hamza Aliyev «Family and school traditions bring up a healthy generation», M. Muradkhanov, A. Alizade, Y. Talibov, A. Agayev, A. Abbasov, S. Quliyev, R. Aliyev, N. Chalabiyev, V. Sukhomlinsky, V. Titarenko, S. Kozlova, T. Markova, O. Zvereva, L. Zagik, D. Dzintere, L. Vavilova, E. Babunova, V. Ivanova, T. Rapina explored opportunities and ways to instill respect for family traditions in preschool children.

\section{AIM AND TASKS / МЕTA ТА ЗАВДАННЯ / ЦЕЛИ И ЗАДАЧИ}

The aim of the article is to theoretically substantiate the pedagogical 
conditions for instilling respect for family traditions in a large group of children studying in preschool institutions, to help parents, educators and researchers in this field to solve the problem.

The following tasks were set for the tasks:

- To determine the theoretical basis for the formation of respect for family traditions in preschool children.

- To clarify the concept of family traditions in pedagogical and psychological literature. children.

- Demonstrate the role of the family in the upbringing of preschool

- Consider family traditions as the basis for the moral upbringing of a preschool child.

- To determine the pedagogical conditions for the formation of respect for family traditions.

\section{THE THEORETICAL BACKGROUNDS / TEOPETИЧHI ОСНОВИ ДОСЛІДЖЕННЯ / ТЕОРЕТИЧЕСКИЕ ОСНОВЫ ИССЛЕДОВАНИЯ}

The ideas, facts, considerations, approaches, concepts that are important for the family traditions of preschool students are selected, modified, based on the pedagogical results of the research. The theoretical basis of the research is a set of scientific and theoretical provisions on the content of family traditions of preschool students. A number of physiological and pedagogical methodological literature were analyzed and relevant generalizations were made. The results were compared with the results of a number of relevant studies. Observations were made in order to study the relevant content in preschools. Observations are based on the fact that the knowledge and skills imparted to students are a whole system. A number of university documents were studied and analyzed in order to study in detail the system of imparting knowledge to students on the relevant topic.

As noted in the pedagogical and psychological literature, the people are the creators of progressive customs and traditions related to the morality, ethical norms and views of society. In order for a nation to survive for many years while preserving its values, it is important for citizens to respect national customs and traditions from an early age. Each new generation must be able to keep alive the existing customs and traditions that reflect the spiritual image of the previous generation. Traditions have always been the regulator and guide of human relations. Because family traditions manifest themselves as a means of preserving and transmitting to the new generation the moral and spiritual 
qualities created by each human race. Due to these characteristics, family traditions are used as a means of education in the national education system. Scholars rightly point out that «the older generation, and at the same time every educator and parent, introduces the younger generation to the rules of moral behavior, customs and traditions». In all cases, people have realized their joys and sorrows, hatred and love, human relations to work, nature, family, homeland, children and friends in the process of mutual communication.

In modern times, family traditions arising from the demands and needs of new family relationships, domestic life, have lost their former limitations, expanded in breadth and depth, and become more comprehensive and effective. Now some family traditions have been improved and are widely used in public educational institutions in terms of appropriate conditions and environment. In modern conditions, it is impossible to imagine a successful solution of family traditions in the upbringing of children without it. The attitude of parents to family traditions is a motivating factor for children.

Thus, family traditions also help to prepare children for family life pedagogically, psychologically, spiritually and morally. Therefore, there is a need to expand research on family traditions. In this case, the manifestations of monotony, simplicity, formalism in the work of education are eradicated, it is replaced by initiative, creativity, vitality. In this regard, it is extremely important to develop and improve long-established family traditions.

\section{RESEARCH METHODS / МЕTOДИ ДОСЛІДЖЕННЯ / МЕTОДЫ ИССЛЕДОВАНИЯ}

This analysis was conducted with the study of the sources related to the subject, the analysis of the results obtained, the analysis and synthesis of the arguments, and also the comparative analysis method.

During the study, the current situation of instilling respect for family traditions in preschool children was observed, children from this age group, parents and caregivers were interviewed, and the answers were tested experimentally.

\section{RESEARCH RESULTS / РЕЗУЛЬTАТИ ДОСЛІДЖЕННЯ / РЕЗУЛЬТАТЫ ИССЛЕДОВАНИЯ}

Instilling a respectful attitude to the family traditions of preschool children helps to develop the personality of children, to form their motives and values in the context of modern culture and to turn it into their own way of life. The child's inner, purposeful, meaningful activity forms moral values. Children 
growing up on this basis fully master family traditions and strive to continue them and pass them on to future generations.

From the first day a child enters preschool, teachers must gather information about their parents, in other words, try to learn from them. At the same time, records should be kept of children, and their level of development should be regularly recorded in a special book.

This work can be done in the following sequence:

a) work done to increase the pedagogical literacy of the family;

b) increase pedagogical awareness in young families;

c) To assist the family in the overall development of the child;

There is no area of human life, whether public or private, that is not connected with the family and its traditions. Because when a person is born, he/she grows up in a family, which is one of the simplest forms of organization of society, and acquires certain ideas, knowledge, skills and habits [4]. It is the diversity, originality, material production and production relations, the distinction of traditions with national, domestic and spiritual specificity of this environment that constitutes a regularity. Every nation has its own family relations and family traditions.

As material and moral values, economic and political relations developed and changed, the forms of the family, family traditions changed, took on different forms and content. The development and destiny of the family were, of course, linked to the progress and destiny of society. In addition to being a social phenomenon, the family also has a natural-biological origin. The family, which is one of the most complex events in public life, has economic, biological, sociopsychological and spiritual aspects.

The family, which is a socio-historical event, family relations, customs, traditions, ceremonies play an important role in the development of spiritual culture. Because customs and traditions, which are socio-historical events, have a class character that pursues the interests of a certain generation, class, group with its content, purpose and idea.

Like other social institutions, it is not possible to imitate certain patterns of activity by increasing family traditions. When we analyze different areas of family life, we see that they are built on different patterns that are different from the reproductions of the majority of each new generation family, and include new families, marriages, parental relationships, households, leisure activities, and so on. Since the family and its values are the product of culture, in practice, the pattern of material and spiritual activity can be the basis for the formation of traditions in the family. It is necessary to start this work from the pre-school age, 
so that family traditions, which combine many important values, can be passed on to future generations. For example, many families have a family tradition of sacrificing in honor of a newborn baby or newlyweds, celebrating the day the child enters school, a father giving his child the first book he read, and collecting a family photo album (now video).

Traditions that beautify the family, enrich its life, life and spirituality exist in sincere, kind, business families. A. Makarenko said about family traditions: «A family without good traditions cannot be an exemplary family. Because tradition, being a strong means of education, significantly contributes to the successful solution of the educational goals of the family» [6, p. 42].

The most effective way to form family traditions in children is through personal example. It is no coincidence that it calls words, sets an example. Recognizing the benefits of personal example in parenting, parents teach their children moral values, promote family traditions, and clarify their role in human life. For this reason, families have a number of responsibilities [2]. Let's look at them:

- The ability of the family to make common decisions and strong family trust. There should be mutual trust and confidence between parents, mutual respect, consultation before making a decision, and not go against each other. The decision must be correct, fair, educative, in the interests of the family.

- Children, including preschoolers, are extremely sensitive. They should not feel insecure between parents and should be forced to take sides in these matters.

Each family has its own traditions. It is possible to raise beautiful generations by taking advantage of these family traditions. The positive moral qualities instilled in children lead to their self-education and self-education.

With the participation of children, the family celebrates holidays or sad days, expresses attitude to educational works, reads fairy tales and children's stories. All this is educational, upbringing and developing. If traditions become a habit, it has a strong impact on the sustainable development of young children. According to K. Ushinsky, habit is the basis of the power of education, the source of educational activity [6, p. 52].

The use of traditions should be based on the following pedagogical and psychological requirements:

1. Taking into account the characteristics of older preschool age.

2. When children use family traditions, the focus should be on the educational opportunities and individual characteristics of the family in which each child grows up. 
3. Ensuring personal example and joint activity of parents and nurseryschool teachers.

Results and prospects for future research. The results of our research, observation and study of the experience of educators have shown that a large group of children (4-5 years old) should be instilled with respect for family traditions from preschool age. From this age onwards, children more clearly assimilate the values instilled in them, try to implement them seriously and responsibly. As a result of working with children properly and correctly, they begin to develop respect for family traditions.

The following pedagogical conditions will be effective in the formation of respectful family traditions among preschool children.

Taking into account the above, we can make the following generalization that in preschool children:

- Respectful attitude of a large group of children to the family, family traditions and the desire to continue them are formed;

- Forming as a person who understands the value and essence of the family;

- Timely identification of family traditions between preschool children and their parents;

- Carrying out relevant development and information-educational work with preschool children and their parents in order to show respect for family traditions.

1. It is recommended that seminars held by the relevant government agencies and educational meetings give a wide place to the promotion of family traditions. It is advisable to use the opportunities of these projects, which carry out awareness-raising activities on the topic of family in the regions (eg, the Committee on Family, Women and Children, «Family Academy», etc.), to convey the essence and content of the work to families from each city, district and village.

2. It is useful to carry out propaganda work on respect for family traditions in order to form the growing generation as a citizen and a person who loves the family and continues its traditions.

3. It is desirable for the child to visit families in order to determine their attitude to family traditions, to study their interest and inclination towards these traditions, and, if necessary, to participate in the implementation of family traditions.

4. As a result of educator and family cooperation, it is recommended to prepare booklets and distribute them to preschools and parents. 
Introducing children to family traditions and instilling in them a sense of respect, both in the family and in preschool institutions, is important in the upbringing of a child. Of course, it is impossible to instill all these traditions in children of this age, because it is beyond their means. Children are given a clear idea of the important traditions through education. Progressive ideas in line with family culture should be concentrated, and a system of inculcating family traditions in children should be created and implemented in an effective way.

\section{CONCLUSIONS AND PROSPECTS FOR FURTHER RESEARCH / ВИСНОВКИ ТА ПЕРСПЕКТИВИ ПОДАЛЬШИХ ДОСЛІДЖЕНЬ / ВЫВОДЫ И ПЕРСПЕКТИВЫ ДАЛЬНЕЙШИХ ИССЛЕДОВАНИЙ}

Our observations show that some parents and pre-school teachers do not pay enough attention to this issue, do not see the nurturing potential of family traditions. However, the process of instilling respect for family traditions should always be in the focus of educators, especially at a time when many of the challenges facing families are increasing. It is necessary to draw children's attention to family traditions at an early age.

Preschool is the age when a person's life is more easily directed, shaped, and imitated by others. Parents and pre-school teachers who know how to use these opportunities in a timely manner play a crucial role in a child's life. There is no other age period in which children's thinking is not formed completely and freely, and their environment does not expand uncontrollably. Parents and preschool teachers who are able to see these opportunities in time can better prepare children for all the challenges they will face. In this case, the work of the family is the responsibility of the teacher, and the work of the teacher is not the responsibility of the parent. Both sides must take full responsibility, especially for inculcating family traditions.

As preschoolers go to kindergarten, their worldview and imagination expand and expand. They try to better understand and comprehend what is going on around them. The first of these factors is family traditions. From the first day they become active members of the family, children see that these family traditions are constantly being performed. In this regard, they try to understand why family traditions are performed and why. Parents and educators are always their closest assistants in this work. Thanks to their attention, patience, care, courtesy, kindness, and restraint, children acquire the knowledge, skills, and habits necessary for life, overcome all difficulties, and eventually acquire the necessary moral and spiritual qualities [9].

The inculcation of family traditions in preschool children is directly related to 
the formation of their spiritual upbringing. As children understand the nature of family traditions, they also begin to develop spiritual qualities. Family traditions, which in themselves are rich in many positive moral qualities, should be an integral part of the formation of a child's spiritual upbringing. The fact that children grow up by adopting family traditions from an early age also strengthens their moral commitment to the family. Family traditions contain many spiritual qualities. Vaccination of children from an early age makes them more easily and objectively assimilated by children of this age. If the first condition for being a good person is moral purity and purity, this work is also rooted in family traditions. Another reason why family traditions are not forgotten and needed today is that they have a positive effect on one's spiritual image.

Children are the ones who will preserve family traditions and pass them on to future generations. From the first moments of their life, they need to become active participants in their family traditions. Only then can they understand how responsible and necessary this work is. As noted in the pedagogical and psychological literature, there are certain age periods of human life in which the characteristics that need to be formed should not be retained for later ages. If they are kept, it will be even more difficult to achieve the desired result, and even impossible. One of these ages is the preschool age.

As you know, children studying in large groups of preschool institutions have a basic, simple idea in each area. When describing this age, Sidgi noted that «the knowledge gained in childhood is like an inscription engraved in stone» [7, p. 22]. In other words, in Sidgi's words, the knowledge gained at this age is engraved in his mind for the rest of his life.

As a result of purposeful work, family traditions can manifest themselves as the basis of moral education of preschool children. Personal qualities and attributes must be formed so that children can be spiritually resilient and overcome the difficulties and obstacles they face in life.

A person is considered a good person if he is far from negative qualities. For this reason, spiritual education is very important in a child's life. Work is carried out in several directions with the spiritual upbringing of the child. Work on the moral education of children continues later, while studying in secondary school, and later. Therefore, parents should pay special attention to the work of spiritual education at this age. According to some educators and psychologists, the foundations of parenting are laid by the age of five. Upbringing up to that age follows a child throughout his life. At the same time, family traditions, upbringing, thinking and behavior have a direct impact on the upbringing and spirit of children. 
Prospects for further research. This analysis serves as a starting point for future research on the relevant topic. Given the importance of the preschool age of students in preserving traditions, we see the importance of a series of studies in this regard.

At the same time, the results of this study will be able to closely assist not only educational institutions, but also government agencies and organizations in their activities. This research will play an important role in regulating familychild, family-preschool, family-state relations. Family traditions combine all the important qualities necessary for the survival of the values of each state, nation. The future of any society depends on the family and the preschool children growing up in that family. In this regard, it will be possible to meet the interests of both the family and the state by instilling family traditions in a timely manner.

\section{REFERENCES / СПИСОК ВИКОРИСТАНИХ ДЖЕРЕЛ / СПИСОК ЛИТЕРАТУРЫ (TRANSLATED AND TRANSLITERATED)}

[1] A. N. Abbasov, National Ethics and Family Ethics: a Textbook for Secondary Specialized Schools. Baku, Azerbaijan: Translator, 2015, 324 p.

[2] A. N. Abbasov, Family pedagogy: A textbook for higher education schools. Baku, Azerbaijan: Translator, 2019, 270 p.

[3] A. N. Abbasov, R. R. Mammadzade, Family Pedagogy (Muntakhabat): A Textbook for Higher Education Schools. Baku, Azerbaijan: Translator, 2019, $272 \mathrm{p}$.

[4] A. N. Abbasov, Pedagogy: a textbook for secondary schools. Baku, Azerbaijan: Translator, 2013, $360 \mathrm{p}$.

[5] A. A. Agayev, The problem of personality formation in the publicpedagogical thought of Azerbaijan. Baku, Azerbaijan: Science, 2005, 288 p.

[6] H. Aliyev, Family and school traditions bring up a healthy generation. Baku, Azerbaijan: Maarif, 1988, 88 p.

[7] N. R. Aliyeva, Family upbringing of preschool children: Textbook. Baku, Azerbaijan: ADPU, 2018, 133 s.

[8] A. A. Alizade, H. A. Alizade, New pedagogical thinking: introduction to psychopedagogy. Baku, Azerbaijan: ADPU publication, 2008, $780 \mathrm{p}$.

[9] A. M. Hasanov, Preschool pedagogy: a textbook for high schools. Baku, Azerbaijan: Nasir, 2000, 387 p.

[10] N. M. Rustamova, History of Preschool Pedagogy: Textbook. Baku, Azerbaijan: Baku University, 2004, 350 p. 


\title{
ВИХОВАННЯ ПОВАГИ ДО СІМЕЙНИХ ТРАДИЦІЙ У ДІТЕЙ ДОШКІЛЬНОГО ВІКУ (В УМОВАХ КОЛЕКТИВУ)
}

\author{
Самедзаде Фаріда Октай гізі, \\ кандидат Інституту освіти Азербайджанської Республіки; \\ викладач Азербайджанського державного \\ педагогічного університету. \\ Баку, Азербайджан. \\ ORCID ID: https://orcid.org/0000-0002-6397-0886 \\ feridesemedzade@gmail.com
}

Анотація. Сімейні традиції відіграють ключову роль у духовному та фізичному розвиткові дітей, у формуванні духовної основи здорового способу життя. Завдяки освітнім впливам діти дошкільного віку розуміють, що $є$ добре, а що погано, звертають увагу на свої дії, поведінку. Повага - один із головних показників духовного світу дитини. Оскільки формування поваги є тривалим процесом, то слід розпочинати цю роботу в ранньому віці. 3 часом у дитини формуються духовні якості, завдяки яким вона зможе спілкуватися 3 родиною, батьками, однолітками, у неї розвивається турботливе, любовне ставлення до людей. Важливими аспектами такого ставлення $\epsilon$ повага й увага. Збереження народом рідної мови, культури та традицій $є$ запорукою його постійного існування. Це пояснює, чому сімейні традиції зберігалися і передавалися впродовж століть. Однією з основних проблем сучасності $€$ захист цілісності соціально-духовного середовища. Сім'я відіграє роль передавача загальнолюдських цінностей, традицій, культурної спадщини, моральних норм та правил, які $\epsilon$ важливими для громадянина, особистості, суспільства. Експерти зазначають, що у XXI столітті потреба людини у сім'ї зменшилася, а сім'я еволюціонує до ліберальних форм співіснування під впливом цивілізації. Однак багато педагогічних досліджень доводять, що це не так. Цінності сім'ї, дітей, затишного дому, матеріального добробуту та дозвілля помітно зросли. Ця глобальна проблема знаходиться в центрі світової уваги. Семінари та конференції служителів ряду впливових організацій, зокрема Організації ісламської співпраці (OIC), на такі теми, як «Шлюб, інститут сім'ї та захист цих цінностей в Організації ісламської співпраці, «Соціальна політика та сім'я в ісламському світі: вимоги та потреби», ще раз доводять актуальність зазначених питань для країн усього світу. Численні заходи, присвячені цій темі, що проводяться у 
нашій країні, $€$ яскравим прикладом матеріальної, моральної підтримки і турботи держави. Як відомо, у грудні 2019 року в Ухані, у центральній китайській провінції Хубей, було виявлено коронавірус COVID-19. Звідти він поширився по всьому світу. У межах боротьби з вірусом майже в усіх країнах було оголошено пандемію й запроваджено карантинний режим. Людям забороняли залишати свої домівки. Отже, до непростої й непередбачуваної світової економічної ситуації додалася ще й пандемія, під час якої родини переживали проблеми, з якими раніше не стикалися. Ситуація змусила переоцінити духовні цінності, відкрити для себе забуті народні сімейні традиції. Адже раніше батьки мало уваги приділяли своїм дітям через зайнятість на роботі. Натомість в умовах пандемії, коли родина опинилася у замкнутому просторі, у батьків з'явилася можливість для спілкування між собою, для постійних тісних контактів із дітьми, для приділення їм належної уваги, а отже, для підтримування сімейних традицій. Навіть після того, як нинішня ситуація зміниться на краще, люди й надалі підтримуватимуть сімейні традиції, які вони перевизначили. Вони не забудуть, що вийшли з цього фінансово та психологічно важкого періоду завдяки підтримці родини. Члени сім'ї пам'ятатимуть, як важливо бути сім'єю, завжди поважатимуть традиції цього суспільного інституту. Як зазначається у педагогічній та психологічній літературі, перші п’ять років дуже важливі для формування особистості людини. Те, що діти дошкільного віку проводять час у сімейному середовищі, $\epsilon$ надзвичайно позитивним фактом, що ще раз доводить, наскільки важливою й потрібною $є$ сім'я. При цьому виховання дитини слід розглядати не лише як виховання особистості, яка росте вдома, а й як виховання людини, яка стане частиною суспільства. А отже, сім'я, як і інші суспільні інституції, мусить докласти зусиль для всебічного розвитку дитини.

Ключові слова: сім'я; традиція; сімейні традиції; дитина дошкільного віку; велика група; виховання дітей; батько та вихователь дошкільної освіти. 


\title{
ВОСПИТАНИЕ УВАЖЕНИЯ К СЕМЕЙНЫМ ТРАДИЦИЯМ У ДЕТЕЙ ДОШКОЛЬНОГО ВОЗРАСТА (В УСЛОВИЯХ КОЛЛЕКТИВА)
}

\author{
Самедзаде Фарида Октай гызы, \\ кандидат педагогических наук \\ Института образования Азербайджанской Республики; \\ преподаватель Азербайджанского государственного \\ педагогического университета. \\ Баку, Азербайджан. \\ ORCID ID: https://orcid.org/0000-0002-6397-0886 \\ feridesemedzade@gmail.com
}

Аннотация. Семейные традиции играют ключевую роль в духовном и физическом развитии детей, в формировании духовной основы здорового образа жизни. Благодаря образовательным воздействиям дети дошкольного возраста понимают, что хорошо, а что плохо, обращают внимание на свои действия, поведение. Уважение - один из главных показателей духовного мира ребенка. Поскольку формирование уважения является длительным процессом, то следует начинать эту работу в раннем возрасте. Со временем у ребенка формируются духовные качества, благодаря которым он сможет общаться с семьей, родителями, сверстниками, у него развивается заботливое, любовное отношение к людям. Важными аспектами такого отношения являются уважение и внимание. Сохранение народом родного языка, культуры и традиций - залог его постоянного существования. Это объясняет, почему семейные традиции сохранялись и передавались на протяжении веков. Одной из главных проблем современности является защита целостности социально-духовной среды. Семья играет роль передатчика общечеловеческих ценностей, традиций, культурного наследия, нравственных норм и правил, которые важны для гражданина, личности и общества. Эксперты отмечают, что в XXI веке потребность человека в семье уменьшилась, а семья эволюционирует к либеральным формам сосуществования под влиянием цивилизации. Однако многие педагогические исследования показывают, что это не так. Ценности семьи, детей, уютного дома, материального благополучия и досуга значительно возросли. Эта глобальная проблема находится в центре мирового внимания. Семинары и конференции служителей ряда влиятельных организаций, включая Организацию исламского сотрудничества 
(ОИС), на такие темы, как «Брак, институт семьи и защита этих ценностей в Организации исламского сотрудничества», «Социальная политика и семья в исламском мире: требования и нужды», еще раз доказывают актуальность указанных вопросов для стран всего мира. Многочисленные мероприятия, посвященные этой теме, проводимые в нашей стране, являются ярким примером материальной, моральной поддержки и заботы государства. Как известно, в декабре 2019 года в Ухане, в центральной китайской провинции Хубей, был обнаружен коронавирус COVID-19. Оттуда он распространился по всему миру. В рамках борьбы с вирусом почти во всех странах была объявлена пандемия и введен карантинный режим. Людям запретили покидать свои жилища. Итак, к непростой и непредсказуемой мировой экономической ситуации добавилась еще и пандемия, во время которой семьи переживали проблемы, с которыми раньше не сталкивались. Ситуация вынудила переоценить духовные ценности, открыть для себя забытые народные семейные традиции. Ведь раньше родители мало внимания уделяли своим детям из-за занятости на работе. Сейчас же в условиях пандемии, когда семья оказалась в замкнутом пространстве, у родителей появилась возможность для общения друг с другом, для постоянных тесных контактов с детьми, для того, чтобы уделять им необходимое внимание, а следовательно, для поддержания семейных традиций. Даже после того, как нынешняя ситуация изменится к лучшему, люди и дальше будут поддерживать семейные традиции, которые они переопределили. Они не забудут, что вышли из этого финансово и психологически сложного периода благодаря поддержке семьи. Члены семьи будут помнить, как важно быть семьей, всегда будут уважать традиции этого общественного института. Как отмечается в педагогической и психологической литературе, первые пять лет очень важны для формирования личности человека. То, что дети дошкольного возраста проводят время в семейной среде, чрезвычайно позитивный факт, который еще раз доказывает, насколько важна и необходима семья. При этом воспитание ребенка следует рассматривать не только как воспитание личности, которая растет дома, но и как воспитание человека, который станет частью общества. А значит, семья, как и другие общественные институции, должна приложить усилия для всестороннего развития ребенка.

Ключевые слова: семья; традиция; семейные традиции; ребенок 
дошкольного возраста; большая группа; воспитание детей; отец и воспитатель дошкольного образования.

\section{REFERENCES (TRANSLATED AND TRANSLITERATED)}

[1] A. N. Abbasov, National Ethics and Family Ethics: a Textbook for Secondary Specialized Schools. Baku, Azerbaijan: Translator, 2015, 324 p.

[2] A. N. Abbasov, Family pedagogy: A textbook for higher education schools. Baku, Azerbaijan: Translator, 2019, 270 p.

[3] A. N. Abbasov, R. R. Mammadzade, Family Pedagogy (Muntakhabat): A Textbook for Higher Education Schools. Baku, Azerbaijan: Translator, 2019, 272 p.

[4] A. N. Abbasov, Pedagogy: a textbook for secondary schools. Baku, Azerbaijan: Translator, 2013, 360 p.

[5] A. A. Agayev, The problem of personality formation in the publicpedagogical thought of Azerbaijan. Baku, Azerbaijan: Science, 2005, 288 p.

[6] H. Aliyev, Family and school traditions bring up a healthy generation. Baku, Azerbaijan: Maarif, 1988, 88 p.

[7] N. R. Aliyeva, Family upbringing of preschool children: Textbook. Baku, Azerbaijan: ADPU, 2018, 133 s.

[8] A. A. Alizade, H. A. Alizade, New pedagogical thinking: introduction to psychopedagogy. Baku, Azerbaijan: ADPU publication, 2008, $780 \mathrm{p}$.

[9] A. M. Hasanov, Preschool pedagogy: a textbook for high schools. Baku, Azerbaijan: Nasir, 2000, 387 p.

[10] N. M. Rustamova, History of Preschool Pedagogy: Textbook. Baku, Azerbaijan: Baku University, 2004, 350 p. 